\title{
PENINGKATAN MENULIS KARYA ILMIAH BERBAHASA INGGRIS DENGAN METODE TASK BASED LANGUAGE TEACHING PRODI PENDIDIKAN BAHASA INGGRIS
}

\author{
Dian Shinta Sari ${ }^{1}$, Hamid Asman ${ }^{2}$, Rodhi $^{3}$ \\ ${ }^{1,2,3}$ Program Studi Pendidikan Bahasa Inggris Fakultas PBS IKIP PGRI Pontianak \\ Jalan Ampera Nomor 88 Pontianak \\ e-mail: dianshintasari@gmail.com
}

\begin{abstract}
Abstrak
Penelitian bertujuan untuk meningkatkan keterampilan menulis mahasiswa Prodi Pendidikan Bahasa Inggris melalui penggunaan metode Task Based Language Teaching (TBLT) dalam menulis karya ilmiah. Desain penelitian menggunakan Penelitian Tindakan Kelas (PTK) yang terdiri atas dua siklus. Subjek penelitian adalah 30 mahasiswa yang mengikuti mata kuliah Introduction to Thesis Writing. Teknik pengumpul data menggunakan pengukuran dan pengamatan langsung. Alat pengumpul data menggunakan tes dan lembar observasi. Teknik analisis data menggunakan triangulasi data. Hasil penelitian menunjukkan bahwa: (1) Metode TBLT terbukti meningkatkan aktivitas belajar mahasiswa, interaksi dalam pembelajaran, dan kemandirian mahasiswa; (2) Peningkatan rerata kemampuan mahasiswa dalam menulis karya ilmiah yang pada siklus I hasilnya 5,21 meningkat menjadi 7,1 pada siklus II; dan (3) Proses belajar mengajar penulisan karya ilmiah lebih berbobot, menarik, dan menyenangkan.
\end{abstract}

Kata Kunci: Task Based Language Teaching, keterampilan menulis, peningkatan.

\begin{abstract}
This study was aimed to improve the writing skill of students English Department by using Task-Based Language Teaching (TBLT) in writing scientific paper. This research design of this study was Classroom Action Research (CAR) consisted of two cicles. The subject of the study were 30 students who took Introduction to Thesis Writing subject. The technique for collecting the data used test and observation. The researcher used quantitative and qualitative data analysis. To obtain qualitative data, the researcher conducted observation and the quantitative data was taken from students'writing score. The results showed that: (1) The TBLT method was proven to increase student learning activities, interaction in learning, and student independence; (2) Increasing the average ability of students in writing scientific papers in the first cycle the results of 5.21 increased to 7.1 in the second cycle; and (3) The process of teaching and learning the writing of scientific works is more weighty, interesting, and enjoyable.
\end{abstract}

Keywords: Task Based Language Teaching, writing skill, improvement.

\section{PENDAHULUAN}

Keterampilan berbahasa yang wajib dimiliki seorang mahasiswa adalah menulis. Ada beberapa alasan yang dikemukakan mengenai pentingnya menulis, walaupun keterampilan menulis banyak yang memandang masih sangat sulit. Menurut Hairston (Suadnyani, 2009: 2) menulis penting karena menulis bisa 
menjadi sarana untuk menemukan sesuatu, memunculkan ide baru, melatih kemampuan mengorganisasikan dan menjernihkan berbagai konsep atau ide, melatih sikap objektif yang ada pada diri seseorang, membantu untuk menyerap dan memproses informasi, serta melatih untuk berpikir aktif.

Kemampuan menulis karya ilmiah merupakan salah satu kemampuan penting bagi mahasiswa dalam rangka memenuhi tuntutan-tuntutan akademik selama masa perkualiahan, seperti menyusun makalah, menyusun laporan observasi, menulis buku, sampai dengan menyusun skripsi atau tugas akhir. Bahkan tidak saja demikian, keterampilan menulis karya ilmiah juga penting bagi masyarakat akademik di perguruan tinggi dalam rangka menyemarakkan dan menggairahkan kebudayaan nasional menyongsong pesatnya perkembangan arus informasi (Supriadi, 2007: 109). Dengan demikian, jelaslah bahwa menulis sangat bermanfaat, meskipun proses menulis terkesan masih sulit.

Kesulitan tersebut tampak pada mata kuliah Introduction to Thesis Writing yang merupakan salah satu mata kuliah yang menekankan pada keterampilan menulis karya ilmiah. Dari hasil pengamatan terhadap tugas pertama mahasiswa semester IV dalam menulis essay writing yang meliputi kemampuan mahasiswa dalam mengorganisasi gagasan, hampir semua mahasiswa tidak dapat menuangkan gagasannya secara kohesif dan runtut. Sebagai akibatnya, ide mahasiswa terkesan jump-up atau tidak terorganisasi dengan baik sehingga paparan dalam paragraf yang dihasilkan tidak mudah dipahami, ditambah lagi dengan keterbatasan pengusaan kosakata Bahasa Inggris serta keterbatasan pengusaan tata bahasa (grammar). Mahasiswa juga cenderung untuk mengabaikan syarat-syarat mekanik seperti ejaan dan tanda baca yang berakibat pada ketidaksempurnaan hasil karya. Kecerobohan-kecerobohan tersebut sudah semestinya juga mendapat perhatian.

Berdasarkan wawancara yang dilaksanakan dengan dosen pengampu mata kuliah didapatkan informasi bahwa pengajar menghadapi kendala dalam menangani masalah mahasiswa di kelas yang meliputi kemampuan mahasiswa dalam mengorganisasi gagasan, pemberian umpan balik, dan kemandirian 
mahasiswa (student learning autonomy). Usaha untuk mengatasi hal tersebut telah dilakukan antara lain dengan memberikan penjelasan dan contoh yang cukup secara teoretis. Pengajar juga mencoba memberikan umpan balik berdasarkan kesalahan umum yang dibuat mahasiswa, namun hal tersebut tidak membantu meningkatkan kesadaran mahasiswa terhadap kekurangan yang terdapat dalam tulisan yang dibuat. Peneliti berpendapat bahwa kemandirian mahasiswa untuk memeriksa dan untuk meningkatkan kemampuan menulis sangatlah kurang.

Wawancara juga dilakukan pada beberapa mahasiswa. Mahasiswa mengatakan bahwa metode pembelajaran yang lebih sering digunakan dosen pada pembelajaran menulis sebelumnya adalah metode ceramah. Mahasiswa lebih banyak menerima dibandingkan menemukan sendiri ilmu pengetahuan tersebut. Dosen jarang memberikan kesempatan kepada mahasiswa untuk bertanya. Hal tersebut disebabkan metode ceramah yang akhirnya membuat mahasiswa lebih banyak bersikap representatif dibandingkan produktif. Permasalahan lain yang didapat pada saat wawancara adalah kurangnya penggunaan media pembelajaran oleh dosen sehingga proses belajar mengajar menjadi monoton.

Pengajaran Bahasa Berbasis Tugas (Task Based Language Teaching/TBLT) merupakan metode pengajaran bahasa yang menggunakan tugas-tugas sebagai unit inti untuk merencanakan dan menyusun bahan instruksional dalam pengajaran bahasa (Richards dan Rodgers, 2001: 223). Dengan kata lain, pokok utama pengajaran bahasa adalah penggunaan tugas-tugas sebagai cara untuk mencapai tujuan pengajaran.

Nunan (1989: 10) menyatakan bahwa task is an activity or action which is carried out as the result of processing or understanding language. Tugas (task) adalah aktivitas atau perbuatan yang terjadi sebagai hasil dari pengolahan atau pengertian bahasa, meliputi kegiatan kelas yang melibatkan siswa memahami, memanipulasi, memproduksi, atau melakukan interaksi dalam bahasa sasaran dengan memobalisasi pengetahuan grammarnya untuk mengekspresikan maksudnya. Melalui tugas, siswa didorong melakukan kegiatan komunikatif yang lebih menekankan makna bukan bentuk, meskipun makna pada hakekatnya tak 
terlepas dari bentuk atau form. Artinya, siswa didorong menggunakan pengetahuan grammar-nya untuk mengungkapkan makna komunikatif.

Berdasarkan definisi tugas, dapat digarisbawahi bahwa tugas melibatkan penggunaan bahasa secara komunikatif dan perhatian pengguna difokuskan pada makna daripada bentuk gramatikal. Hal tersebut bukan berarti bentuk tidak penting, bentuk dan makna sangat saling berhubungan. Tata bahasa ada untuk memungkinkan pengguna bahasa mengekspresikan makna komunikatif.

Dalam rancangan TBLT terdapat sedikitnya enam jenis tugas yang dapat diterapkan guna mendukung keberhasilan pembelajaran bahasa (Willis, 1996: 2627). Jenis-jenis tugas tersebut yakni: (1) Mengurutkan daftar (listing); (2) Mengatur dan Menyortir (ordering and sorting); (3) Membandingkan (comparing); (4) Memecahkan masalah (problem solving); (5) Berbagi pengalaman pribadi (sharing personal experiences); dan (6) Tugas kreatif (creative tasks).

Berdasarkan permasalahan yang telah diuraikan, peneliti tertarik untuk menerapkan suatu model pembelajaran yang baru melalui metode Task Based Language Teaching (TBLT) untuk meningkatkan keterampilan menulis. Adapun tujuan penelitian adalah untuk meningkatkan keterampilan menulis mahasiswa semester IV Prodi Pendidikan Bahasa Inggris melalui penggunaan metode TBLT.

\section{METODE}

Metode penelitian yang digunakan adalah Penelitian Tindakan Kelas (PTK) atau Classroom Action Research (CAR). Proses pada PTK terdiri dari empat tahap, yaitu tahap perencanaan (planning), tahap pelaksanaan (implementing), tahap pengamatan (observation), dan tahap refleksi (reflecting). Gambar proses dasar PTK dapat dilihat sebagai berikut. 




\section{Gambar 1 Bagan Alur Rancangan Penelitian Tindakan Kelas}

Subjek penelitian adalah mahasiswa kelas A pagi semester V Prodi Pendidikan Bahasa Inggris IKIP Pontianak yang berjumlah 30 mahasiswa. Penentuan subjek penelitian didasarkan secara sederhana dengan memilih salah satu kelas yang memiliki kendala dalam pembelajaran menulis karya ilmiah. Dari hasilnya yaitu kelas A pagi semester V, karena berdasarkan informasi dari dosen yang mengampu mata kuliah Writing, kelas A pagi memiliki kemampuan menulis yang paling rendah dibandingkan dengan tiga kelas lainnya.

Teknik pengumpul data menggunakan pengukuran dan pengamatan langsung. Alat pengumpul data berupa tes menulis yang diberikan di awal penelitian dan di akhir masing-masing siklus dan lembar observasi. Teknik analisis data menggunakan triangulasi data.

\section{HASIL DAN PEMBAHASAN}

Deskripsi hasil penelitian diuraikan dalam tahapan yang berupa siklus-siklus pembelajaran yang dilakukan. Tindakan kelas yang dilaksanakan dalam menerapkan metode TBLT pada keterampilan menulis karya ilmiah di kelas A pagi semester V di Prodi Pendidikan Bahasa Inggris IKIP PGRI Pontianak adalah sebagai berikut. 


\section{Siklus I}

\section{Perencanaan}

Peneliti dan kolaborator berdiskusi tentang aktivitas pelaksanaan TBLT di kelas termasuk pembuatan SAP, instrumen penelitian, dan tes menulis.

\section{Pelaksanaan dan Pengamatan}

Peneliti mengajar menulis karya ilmiah dengan TBLT. Peneliti dan kolaborator mencatat semua aktivitas di kelas dengan menggunakan lembar observasi dan catatan kaki di setiap pertemuan.

\section{Refleksi}

Peneliti dan kolaborator merefleksi semua aktivitas belajar mengajar pada akhir siklus I. Refleksi tersebut meliputi implementasi TBLT pada pertemuan pertama dan kedua, situasi di kelas ketika TBLT diimplementasikan dan refleksi terhadap nilai menulis mahasiswa. Dari hasil refleksi tersebut peneliti dan kolaborator menyimpulkan bahwa perlu untuk melanjutkan pada siklus II.

Hasil penelitian pada siklus I dapat dilihat pada tabel berikut.

Tabel 1 Perolehan Nilai Mahasiswa Siklus I

\begin{tabular}{cccccccc}
\hline & & \multicolumn{5}{c}{ Kemampuan Menulis dan Skor } & \\
\cline { 3 - 6 } No & $\begin{array}{c}\text { Kode } \\
\text { Mahasiswa }\end{array}$ & $\begin{array}{c}\text { Isi } \\
(\mathbf{C})\end{array}$ & $\begin{array}{c}\text { Organisasi } \\
(\mathbf{O})\end{array}$ & $\begin{array}{c}\text { Tata } \\
\text { Bahasa } \\
(\mathbf{G})\end{array}$ & $\begin{array}{c}\text { Kosakata } \\
(\mathbf{V})\end{array}$ & $\begin{array}{c}\text { Penulisan } \\
(\mathbf{M})\end{array}$ & Total \\
\hline 1 & AJ & 12 & 6 & 6 & 4,5 & 4,5 & \\
2 & AS & 6 & 4 & 4 & 3 & 3 & 5,2 \\
3 & ALL & 3 & 2 & 2 & 3 & 1,5 & 2,8 \\
4 & CDS & 9 & 4 & 6 & 4,5 & 3 & 6,6 \\
5 & CLP & 6 & 4 & 4 & 4,5 & 4,5 & 5,7 \\
6 & DSW & 3 & 2 & 2 & 1,5 & 1,5 & 2,5 \\
7 & DNH & 9 & 6 & 6 & 4,5 & 4,5 & 7,5 \\
8 & DAM & 3 & 2 & 2 & 1,5 & 1,5 & 2,5 \\
9 & DF & 3 & 2 & 2 & 1,5 & 1,5 & 2,5 \\
10 & DA & 3 & 4 & 4 & 3 & 1,5 & 3,8 \\
11 & DN & 9 & 6 & 6 & 4,5 & 3 & 7,1 \\
12 & EM & 3 & 2 & 2 & 3 & 1,5 & 2,8 \\
13 & EER & 3 & 2 & 2 & 3 & 1,5 & 2,8 \\
14 & FA & 9 & 6 & 4 & 4,5 & 1,5 & 6,2 \\
15 & FU & 12 & 6 & 4 & 4,5 & 3 & 7,3 \\
16 & FP & 6 & 4 & 4 & 3 & 3 & 5 \\
17 & FN & 6 & 4 & 4 & 3 & 1,5 & 4,6 \\
\hline
\end{tabular}




\begin{tabular}{|c|c|c|c|c|c|c|c|}
\hline 18 & $\mathrm{FE}$ & 6 & 4 & 4 & 3 & 3 & 5 \\
\hline 19 & HR & 9 & 4 & 6 & 3 & 3 & 6,2 \\
\hline 20 & HS & 3 & 4 & 4 & 3 & 3 & 4,2 \\
\hline 21 & IG & 9 & 4 & 2 & 4,5 & 1,5 & 5,2 \\
\hline 22 & KTY & 9 & 6 & 6 & 4,5 & 3 & 7,1 \\
\hline 23 & KM & 9 & 4 & 6 & 4,5 & 4,5 & 7 \\
\hline 24 & LD & 12 & 6 & 4 & 3 & 3 & 7 \\
\hline 25 & LS & 6 & 4 & 4 & 4,5 & 1,5 & 5 \\
\hline 26 & MA & 3 & 2 & 4 & 1,5 & 1,5 & 3 \\
\hline 27 & MR & 9 & 6 & 4 & 4,5 & 3 & 6,6 \\
\hline 28 & MY & 9 & 4 & 4 & 4,5 & 3 & 6,1 \\
\hline 29 & NA & 3 & 2 & 2 & 1,5 & 1,5 & 6,6 \\
\hline \multirow[t]{3}{*}{30} & $\mathrm{RS}$ & 6 & 4 & 4 & 3 & 1,5 & 4,6 \\
\hline & Skor Total & 198 & 120 & 118 & 102 & 75 & 156,5 \\
\hline & Mean & 6,6 & 4 & 3,9 & 3,4 & 2,5 & 5,2 \\
\hline
\end{tabular}

Berdasarkan Tabel 1, dapat dilihat bahwa hasil tes formatif untuk siklus I nilai tertinggi 8,2 dan nilai terendah 2,5. Nilai rata-rata tes menulis siklus I diperoleh 5,21 dengan kategori $\mathrm{C}$.

Hasil pengamatan pada siklus I, tingkat partisipasi mahasiswa pada keterampilan menulis ilmiah dinilai cukup berhasil membuat mahasiswa tertarik untuk menulis. Mahasiswa yang biasanya jika menulis hanya diberi topik lalu mengembangkan topik tadi menjadi sebuah tulisan karya ilmiah, terlihat lebih tertarik pada saat pembelajaran dengan menggunakan TBLT. Terlihat bahwa mahasiswa merasa senang dan bersemangat walau ada yang sebagian masih malumalu saat diminta untuk menjawab pertanyaan dari dosen seputar tugas yang ditampilkan. Oleh karenanya, pembelajaran masih perlu perbaikan dan dilanjutkan ke siklus II.

Berdasarkan pada hasil siklus I, dosen dan kolaborator berupaya meningkatkan kegiatan pembelajaran pada siklus II dengan memperhatikan kelemahan yang ada pada siklus I, baik dari aspek dosen, mahasiswa, media maupun model pembelajaran.

\section{Siklus II}

Siklus II dilakukan karena masih terdapat kelemahan yang ditemukan dalam proses pembelajaran di siklus I. Pada siklus II, proses pembelajaran masih sama 110 
dengan siklus I. Bedanya pada siklus II lebih menyempurnakan kegiatan yang dilakukan pada siklus I.

Awal pembelajaran dosen menyampaikan tujuan pembelajaran dengan menjelaskan langkah-langkah yang akan ditempuh mahasiswa selama proses pembelajaran. Kemudian dosen menjelaskan kepada mahasiswa bahwa fokus pembelajaran menulis karya ilmiah adalah preparing the final paper, grammar and style tips, final touches, sample term papers and report, dan giving an oral presentation. Selama pembelajaran, mahasiswa dibagi dalam 10 kelompok dan tiap kelompok terdiri atas 3 mahasiswa dengan kemampuan heterogen.

Setiap kegiatan pembelajaran menulis karya ilmiah mahasiswa mengerjakan tugas-tugas yang diberikan dosen berupa exercise on finding information, exercise on stating thesis statement, exercise in making a tentative outline, and revise your outline and draft. Kegiatan tersebut dilakukan secara berkelompok untuk mengaktivasi kemampuan berkomunikasi di kelas. Kemudian hasil tersebut dipresentasikan mengikuti tahap perencanaan (planning) dan pelaporan (reporting) sebelumnya. Post task diberikan dalam bentuk dialog singkat.

Memasuki fase language focus, contoh-contoh tulisan ilmiah yang terkait dengan pokok bahasan dibahas untuk didiskusikan secara bersama-sama. Pada fase practice, mahasiswa menulis kembali karya ilmiah untuk menghasilkan outcome yang kemudian dipresentasikan dan diberikan komentar oleh rekanrekannya. Bagi contoh tulisan karya ilmiah yang baik akan diberikan applause oleh peneliti dan rekan-rekan mahasiswa lainnya.

Hasil akhir pengamatan pada siklus II diperoleh tingkat partisipasi mahasiswa meningkat seiring dengan peningkatan skor total dari masing-masing komponen.

Tabel 2 Perolehan Nilai Mahasiswa Siklus II

\begin{tabular}{cccccccc}
\hline & & \multicolumn{5}{c}{ Kemampuan Menulis dan Skor } & \\
\cline { 3 - 7 } No & $\begin{array}{c}\text { Kode } \\
\text { Mahasiswa }\end{array}$ & $\begin{array}{c}\text { Isi } \\
(\mathbf{C})\end{array}$ & $\begin{array}{c}\text { Organisasi } \\
(\text { O) }\end{array}$ & $\begin{array}{c}\text { Tata } \\
\text { Bahasa } \\
(\mathbf{G})\end{array}$ & $\begin{array}{c}\text { Kosakata } \\
(\text { V) }\end{array}$ & $\begin{array}{c}\text { Penulisan } \\
(\text { M) }\end{array}$ & Total \\
\hline 1 & AJ & 12 & 8 & 6 & 6 & 6 & 9,5 \\
\hline
\end{tabular}




\begin{tabular}{cccccccc}
\hline 2 & AS & 6 & 4 & 6 & 4,5 & 4,5 & 6,2 \\
3 & ALL & 9 & 6 & 4 & 3 & 1,5 & 5,8 \\
4 & CDS & 12 & 8 & 6 & 4,5 & 4,5 & 8,7 \\
5 & CLP & 9 & 6 & 6 & 4,5 & 4,5 & 7,5 \\
6 & DSW & 6 & 4 & 6 & 4,5 & 4,5 & 6,2 \\
7 & DNH & 12 & 8 & 6 & 6 & 6 & 9,5 \\
8 & DAM & 9 & 6 & 4 & 4,5 & 3 & 6,6 \\
9 & DF & 6 & 4 & 6 & 3 & 1,5 & 5,1 \\
10 & DA & 9 & 4 & 4 & 3 & 3 & 5,7 \\
11 & DN & 12 & 8 & 6 & 4,5 & 3 & 8,3 \\
12 & EM & 12 & 6 & 6 & 4,5 & 3 & 7,8 \\
13 & EER & 9 & 6 & 4 & 4,5 & 3 & 6,6 \\
14 & FA & 9 & 6 & 4 & 4,5 & 3 & 6,6 \\
15 & FU & 12 & 8 & 8 & 6 & 6 & 10 \\
16 & FP & 9 & 6 & 4 & 3 & 1,5 & 5,8 \\
17 & FN & 9 & 6 & 4 & 4,5 & 3 & 6,6 \\
18 & FE & 9 & 6 & 6 & 4,5 & 4,5 & 7,5 \\
19 & HR & 9 & 6 & 6 & 4,5 & 3 & 7,1 \\
20 & HS & 9 & 6 & 6 & 4,5 & 4,5 & 7,5 \\
21 & IG & 9 & 6 & 4 & 4,5 & 3 & 6,6 \\
22 & KTY & 12 & 8 & 4 & 4,5 & 3 & 7,8 \\
23 & KM & 9 & 6 & 6 & 4,5 & 3 & 7,1 \\
24 & LD & 9 & 6 & 6 & 4,5 & 3 & 7,1 \\
25 & LS & 6 & 4 & 4 & 4,5 & 3 & 5,3 \\
26 & MA & 9 & 4 & 4 & 3 & 3 & 5,7 \\
27 & MR & 9 & 6 & 6 & 4,5 & 3 & 7,1 \\
28 & MY & 9 & 4 & 6 & 4,5 & 4,5 & 7 \\
29 & NA & 12 & 8 & 6 & 4,5 & 4,5 & 8,7 \\
30 & RS & 6 & 4 & 6 & 4,5 & 4,5 & 6,2 \\
\hline & Skor Total & $\mathbf{2 7 9}$ & $\mathbf{1 7 8}$ & $\mathbf{1 6 0}$ & $\mathbf{1 3 2}$ & $\mathbf{1 0 8}$ & $\mathbf{2 1 3 , 2}$ \\
\hline & Mean & $\mathbf{9 , 3}$ & $\mathbf{5 , 9}$ & $\mathbf{5 , 3}$ & $\mathbf{4 , 4}$ & $\mathbf{3 , 6}$ & $\mathbf{7 , 1}$ \\
\hline
\end{tabular}

Tabel 2 menunjukkan bahwa keseluruhan komponen menulis karya ilmiah mengalami peningkatan. Skor rata-rata awal mahasiswa 5,21 pada siklus I meningkat menjadi 7,1 pada siklus II. Dengan kata lain, dari tingkat fair (cukup) pada siklus I menjadi good (baik) pada siklus II. Nilai tertinggi meningkat dari 8,2 
siklus I menjadi 9,5 pada siklus II dan nilai terendah 2,5 pada siklus I menjadi 5,3 pada siklus II.

Pengamatan keseharian terhadap pembelajaran di kelas sebagai variabel proses dalam penelitian juga menunjukkan bahwa mahasiswa memiliki sikap positif terhadap proses pembelajaran tersebut. Mahasiswa frekuentif melakukan komunikasi ketika mengerjakan tasks, mengangkat tangan untuk memberikan ide atau komentar dalam diskusi dan mengumpulkan tugas tepat pada waktunya.

Hasil penelitian membuktikan bahwa melalui metode TBLT dapat meningkatkan keterampilan menulis karya ilmiah mahasiswa. Peningkatan keterampilan menulis karya ilmiah terlihat dari perbandingan nilai rata-rata siklus I dengan nilai rata-rata siklus II. Hal teresbut disebabkan oleh intensifnya pembelajaran tentang menulis karya ilmiah yang diberikan melalui aktivitas TBLT. Ellis (Brown, 2007: 50) menyatakan bahwa tugas pembelajaran berbasis mengajar di pengajaran bahasa adalah jantung pengajaran bahasa yang komunikatif. Tugas pembelajaran berbasis mengajar membuat perbedaan penting antara tugas sasaran, mahasiswa harus mencapai di luar kelas, dan tugas pedagogis, yang merupakan inti dari kegiatan di kelas.

Hasil penelitian juga menunjukkan bahwa penerapan Task Based Language Teaching (TBLT) dapat meningkatkan partisipasi aktif mahasiswa, interaksi belajar mahasiswa berjalan cukup baik dikarenakan mahasiswa mulai memahami apa yang harus dikerjakan. Mahasiswa mulai mengevaluasi tulisannya berdasarkan masukan dari temannya dan dosen memberikan dorongan pada mahasiswa untuk memperbaiki tulisannya sebelum diserahkan kepada dosen untuk diberi masukan.

Suasana kelas lebih hidup pada setiap siklusnya. Hal tersebut disebabkan oleh adanya variasi tugas yang diberikan dan adanya saling mengevaluasi antara mahasiswa baik individual maupun kelompok dan kualitas bahasa dalam menulis karya ilmiah ada meningkat dalam setiap siklus. Walaupun kesalahan tata bahasa tetap ada, pada umumnya kesalahan tersebut berkurang pada siklus berikutnya. 
Berdasarkan hasil observasi, pembelajaran dengan metode TBLT sudah berjalan baik, begitu juga dengan kerja sama antara mahasiswa. Semua mahasiswa berkomunikasi dalam tasks, mengangkat tangan untuk memberikan ide atau komentar dalam diskusi dan mengumpulkan tugas tepat pada waktunya. Hal tersebut sesuai dengan pendapat Nunan (1989: 12) bahwa tugas pengajaran berbasis bahasa umumnya ditandai dengan perkembangan dalam pendekatan komunikatif. Dibutuhkan tugas didefinisikan dalam berbagai cara sebagai elemen sentral dalam desain silabus dan pengajaran. Dengan kata lain, tugas pengajaran berbasis bahasa ditentukan dalam hal tugas-tugas belajar, jadi fokusnya adalah pada proses daripada produk.

\section{SIMPULAN}

Berdasarkan langkah-langkah penelitian yang terdiri dari dua siklus yang telah dilakukan dalam pembelajaran penulisan karya ilmiah, dapat disimpulkan bahwa: (1) Metode pembelajaran TBLT dapat dipergunakan sebagai upaya peningkatan keterampilan menulis mahasiswa. Metode TBLT terbukti meningkatkan aktivitas belajar mahasiswa, interaksi dalam pembelajaran, dan kemandirian mahasiswa. Mahasiswa berinteraksi dengan mahasiswa lainnya yang dapat menunjang kemandirian agar tidak sepenuhnya tergantung kepada dosen; (2) Peningkatan aktivitas dan interaksi tersebut mengakibatkan adanya peningkatan kemampuan mahasiswa selama proses pembelajaran. Peningkatan mahasiswa juga dapat dilihat dari meningkatnya rerata kemampuan mahasiswa dalam menulis karya ilmiah yang pada siklus I hasilnya 5,21 meningkat menjadi 7,1 pada siklus II; dan (3) Proses pembelajaran menulis karya ilmiah mengalami kemajuan dan perbaikan. Proses belajar mengajar penulisan karya ilmiah lebih berbobot, menarik, dan menyenangkan. Mahasiswa cenderung lebih siap karena diwajibkan konsultasi 1 atau 2 hari sebelum presentasi.

\section{DAFTAR PUSTAKA}

Ellis, R. 2007. Task-Based Language Learning and Teaching. Oxford: University Press. 
Nunan, D. 1989. Designing Tasks for the Communicative Classroom. Cambridge: Cambridge University Press.

Richards, J. C. \& Rodgers, T. S. 2001. Approaches and Methods in Language Teaching. Second Edition. Cambridge: Cambridge University Press.

Suadnyani, N. W. 2009. Penerapan Strategi POWERS untuk Meningkatkan Keterampilan Menulis Argumentasi. Singaraja: Universitas Pendidikan Ganesha.

Supriadi. 2007. Kurikulum Sains dalam Proses Pembelajaran Sains. Yogyakarta: Pustaka Tempel Sari.

Willis, J. 1996. A Frame for Task-Based Learning. London: Longman. 